\title{
Environmental Legislation and the Regulation of Waste Management in Sweden
}

CSI Resource Systems, Incorporated

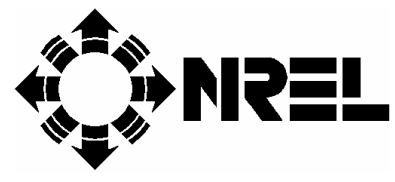

National Renewable Energy Laboratory 1617 Cole Boulevard Golden, Colorado 80401-3393

A national laboratory of the U.S. Department of Energy Managed by Midwest Research Institute for the U.S. Department of Energy under contract No. DE-AC36-83CH10093 


\section{Environmental Legislation and the Regulation of Waste Management in Sweden}

CSI Resource Systems, Incorporated

NREL Technical Monitor: Philip Shepherd

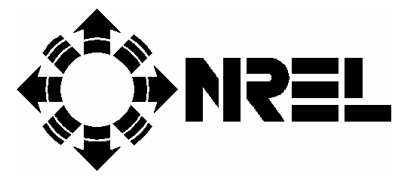

National Renewable Energy Laboratory 1617 Cole Boulevard

Golden, Colorado 80401-3393

A national laboratory of the U.S. Department of Energy Managed by Midwest Research Institute for the U.S. Department of Energy under contract No. DE-AC36-83CH10093

Prepared under Subcontract No. HZ-2-12028-03

May 1995 


\section{NOTICE}

This report was prepared as an account of work sponsored by an agency of the United States government. Neither the United States government nor any agency thereof, nor any of their employees, makes any warranty, express or implied, or assumes any legal liability or responsibility for the accuracy, completeness, or usefulness of any information, apparatus, product, or process disclosed, or represents that its use would not infringe privately owned rights. Reference herein to any specific commercial product, process, or service by trade name, trademark, manufacturer, or otherwise does not necessarily constitute or imply its endorsement, recommendation, or favoring by the United States government or any agency thereof. The views and opinions of authors expressed herein do not necessarily state or reflect those of the United States government or any agency thereof.

Available to DOE and DOE contractors from:

Office of Scientific and Technical Information (OSTI)

P.O. Box 62

Oak Ridge, TN 37831

Prices available by calling 423-576-8401

Available to the public from:

National Technical Information Service (NTIS)

U.S. Department of Commerce

5285 Port Royal Road

Springfield, VA 22161

703-605-6000 or 800-553-6847

or

DOE Information Bridge

http://www.doe.gov/bridge/home.html 


\section{Contents}

$\underline{\text { Page }}$

Purpose $\ldots \ldots \ldots \ldots \ldots \ldots \ldots \ldots \ldots \ldots \ldots \ldots \ldots \ldots \ldots \ldots \ldots \ldots \ldots$

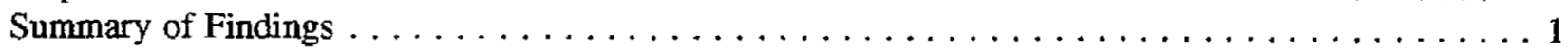

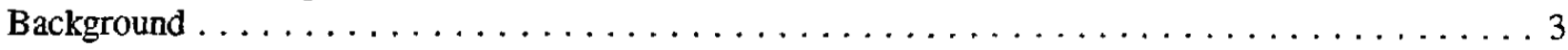

Overview of Political/Judicial Structure $\ldots \ldots \ldots \ldots \ldots \ldots \ldots \ldots \ldots \ldots$

The General Court $\ldots \ldots \ldots \ldots \ldots \ldots \ldots \ldots \ldots \ldots \ldots \ldots \ldots$

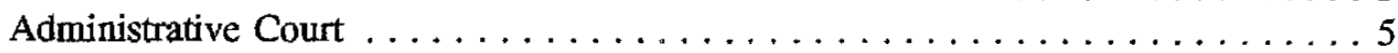

Agencies, Counties, and Municipalities $\ldots \ldots \ldots \ldots \ldots \ldots \ldots$

Overview of Environmental Policy $\ldots \ldots \ldots \ldots \ldots \ldots \ldots \ldots \ldots \ldots \ldots \ldots \ldots \ldots \ldots \ldots$

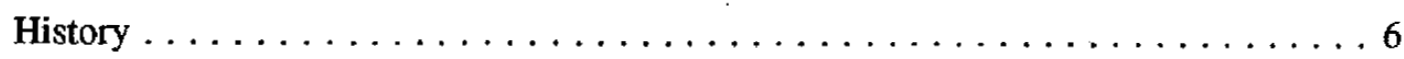

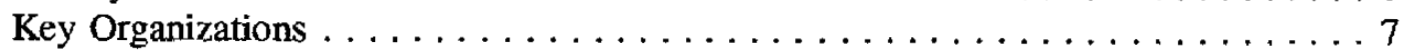

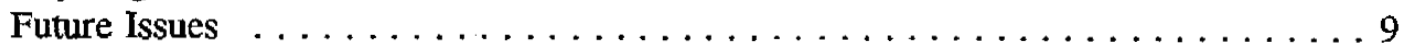

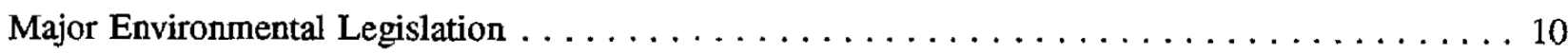

Key Provisions of Major General Environmental Legislation $\ldots \ldots \ldots \ldots \ldots \ldots \ldots$

The Nature Conservancy Act (1964) and Nature Conservancy Ordinance (1976) $\ldots 10$

The Environmental Protection Act and Environmental Protection Ordinance . . . . 10

The Act on Products Hazardous to Health and to the Environment $\ldots \ldots \ldots \ldots 12$

The Environmental Damage Act . . . . . . . . . . . . . . . 12

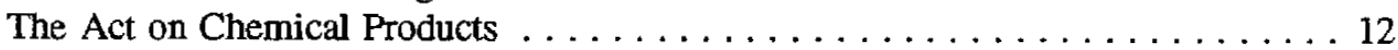

The Ordinance on Vehicle Exhausts $\ldots \ldots \ldots \ldots \ldots \ldots \ldots \ldots \ldots \ldots$

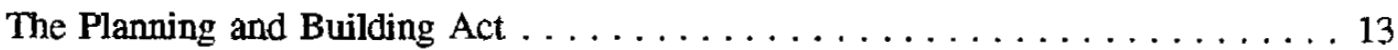

The Natural Resources Act . . . . . . . . . . . . . . . . 13

The Vehicle Scrapping Act and the Vehicle Scrapping Ordinance ........ 13

Key Provisions of Major Legislation Specific to Solid Waste Management . . . . . . . 13

The Cleansing Act and the Cleansing Ordinance . . . . . . . . . . . 13

The Waste Bill . . . . . . . . . . . . . . . . . . . . . . . 14

Recent Legislation . . . . . . . . . . . . . . . . . . 14

Regulation of Emissions from Waste-to-Energy Facilities $\ldots \ldots \ldots \ldots \ldots \ldots \ldots \ldots$

Moratorium on the Licensing of New Waste-to-Energy Facilities $\ldots \ldots \ldots \ldots \ldots$

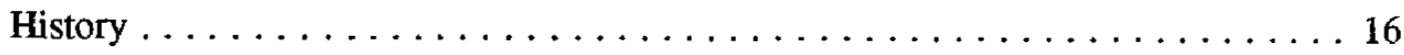

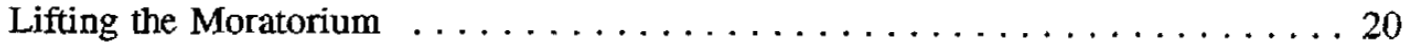




\section{Contents (Continued)}

$\underline{\text { Page }}$

Waste Generation, Collection, Processing, Treatment, and Disposal in Sweden . . . . . . . 24

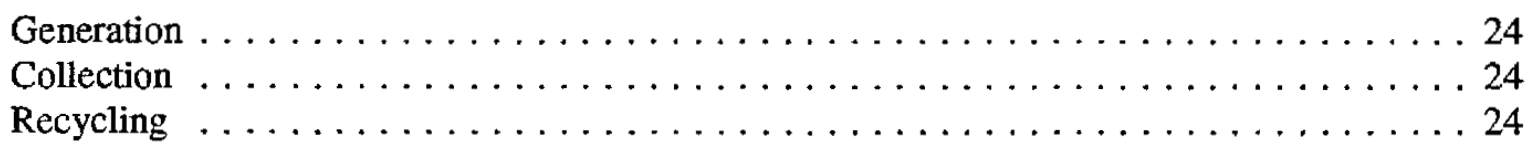

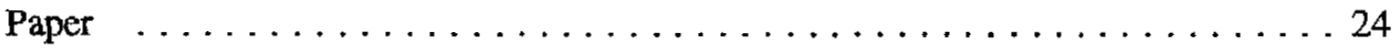

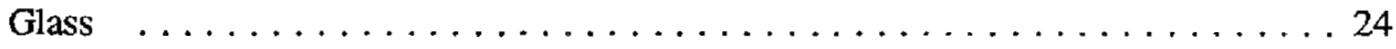

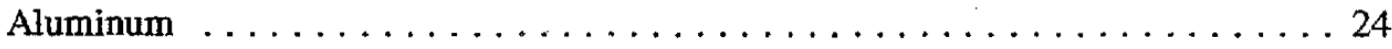

Processing, Treatment, and Disposal $\ldots \ldots \ldots \ldots \ldots \ldots \ldots \ldots \ldots \ldots \ldots \ldots$

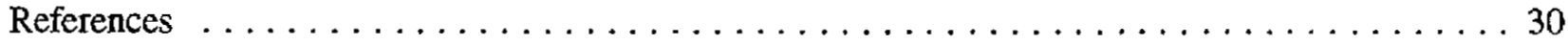

Appendix A: Meetings and Tours Conducted in Sweden 


\section{List of Figures}

$\underline{\text { Page }}$

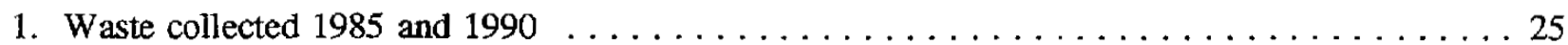

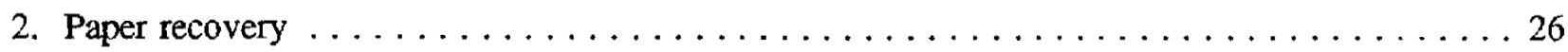

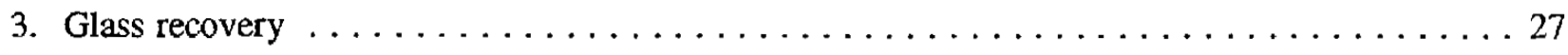

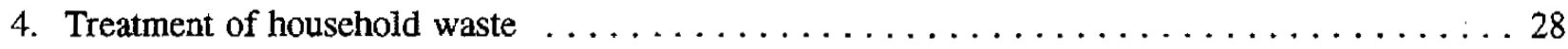

\section{List of Tables}

$\underline{\text { Page }}$

1. Key Organizations Involved in Implementing Environmental Regulations

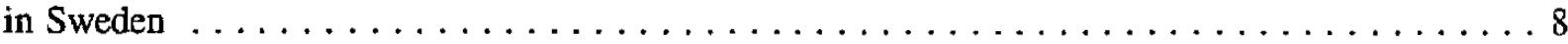

2. Incineration Plants in Sweden April $1992 \ldots \ldots \ldots \ldots \ldots \ldots \ldots \ldots \ldots \ldots \ldots$

3. Emission Limits for Various Waste-to-Energy Facilities $\ldots \ldots \ldots \ldots \ldots \ldots \ldots \ldots$

4. Toxic Equivalent Factors $\ldots \ldots \ldots \ldots \ldots \ldots \ldots \ldots \ldots \ldots \ldots \ldots \ldots \ldots \ldots \ldots \ldots$

5. Recommended Emission Requirements $\ldots \ldots \ldots \ldots \ldots \ldots \ldots \ldots \ldots \ldots \ldots \ldots \ldots$

6. Yearly Emissions from Waste Incineration -1985 and $1991 \ldots \ldots \ldots \ldots \ldots \ldots \ldots$ 


\section{Acknowledgments}

A study of this depth and nature could not have been conducted without the support and participation of a large number of organizations and individuals, both in the U.S. and Sweden. To those listed below, CSI Resource Systems, Incorporated extends its sincere thanks and appreciation.

We are especially grateful to Dr. Christofer Rappe, University of Umea; Mr. Claes Akesson, Ministry of the Environment and Natural Resources; Mr. Jan Bergstrom, Miljokonsulterna; and Dr. Stellan Marklund, University of Umea. We are also very grateful to Dr. Yakowitz, Organization for Economic Co-Operation and Development (OECD), for his recommendation and assistance in setting this trip itinerary.

This study would have not have possible without the time and expertise given by the men and women in Sweden listed in Appendix A. We offer our sincere thanks to these individuals for their support and interest.

Finally, we thank Messrs. Donald Walter, Kurt Sisson, and Simon Friedrich, of the U.S Department of Energy (DOE), and Mr. Philip Shepherd of the National Renewable Energy Laboratory (NREL), Golden, Colorado, for their support and assistance on this project. Funding for this effort was provided by NREL on behalf of DOE. 


\section{Purpose}

This study examines the regulatory aspects of waste management in Sweden, with a particular emphasis on regulating organic compounds produced by waste-to-energy facilities. Since the early $1960 \mathrm{~s}$, waste-toenergy has played a significant role in managing waste in Sweden. In 1993, more than 50\% of the municipal solid waste available for treatment or disposal following source separation efforts was processed in one of the 21 waste-to-energy facilities operating in Sweden. This report examines Sweden's regulatory environment, its history of setting emission limits on waste management facilities, and the current status of regulations.

\section{Summary of Findings}

Sweden has an integrated waste management system which incorporates source reduction, reuse, recycling, separation and composting, waste-to-energy, and landfilling. In Sweden, there are 21 waste-to-energy facilities ranging in capacity from 5,000 tons to 300,000 tons per year, 11 separation or composting facilities, and more than 200 landfills.

Sweden has legislation and regulations which will, over the next few years, result in continuing changes in waste and materials management practices in accordance with a hierarchy of avoidance or minimization, materials and energy recovery, and final disposal. The current trends in Swedish waste management include expanding "producer responsibility" to cover additional waste stream components, and eliminating landfilling untreated, unseparated waste.

The approach used in Sweden to implement environmental policy involves various licensing and permitting processes, planning activities, surveillance measures, and sanctions. In addition, Sweden employs economic instruments as taxes on emissions. In the case of waste management, the government also exercises significant operating control over collection, processing, and disposal, either directly or via contractual relationships with the private sector.

The responsibility for enforcing environmental laws is distributed among the national government, regional authorities, and local municipalities. The Environment Protection Agency is the central government authority in matters related to the environment. The majority of decisions that govern implementation of environmental activities in Sweden are, however, made by other organizations. These include other national authorities, the Franchise Board, the county administrations, and the municipalities.

Environmental regulation in Sweden has a long history, beginning in the 1960s. The first major piece of legislation was the Nature Conservancy Act, passed in 1964. In 1967, the Environmental Protection Agency was set up. In 1968, the Environmental Advisory Committee was established to act as a government consultant in environmental affairs. In 1969, the Environment Protection Act was passed. This, along with the Act on Products Hazardous to Health and to the Environment, passed in 1973, form the key legislative structure for regulating the environment in Sweden.

The first public Cleansing Act was issued in 1972, placing responsibility for collection and transport of domestic solid waste on municipalities. In 1979, municipalities were also given responsibility for ensuring treatment of solid waste. It is left to each municipality, with guidance from the Environmental Protection Agency and the county administrations, to establish its own public cleansing acts specifically addressing the management of domestic and other solid wastes in their jurisdictions. The costs of the municipal waste management system are covered via a special fee for each household or homeowner.

Waste-to-energy facilities, depending on their annual throughput capacity, are required to obtain their license from the Franchise Board or the county administration. The emission limits and operational 
requirements governing performance and testing of the facilities are described in the individual permits. The Environmental Protection Agency issues guidelines relating to emission levels for each facility in Sweden.

On February 13, 1985, the Swedish EPA issued a moratorium on constructing new municipal solid waste incinerators. This moratorium was because data indicated that municipal incinerators were a major source of dioxins in the environment, and data from 1984 showed the presence of dioxins in adipose tissues and mothers' milk. This, coupled with the findings that dioxins were extremely toxic to laboratory animals, combined to raise significant public concern.

At the time of the moratorium, more than half of the domestic waste collected in Sweden was incinerated. In May 1985, the government assigned the then-National Energy Administration and the Environmental Protection Agency the task of investigating engineering requirements and emission limits that should be imposed on waste incineration. In November 1985, a research group was formed within the National Environmental Protection Board to investigate dioxin emissions from municipal waste incinerators, to correlate these emissions with potential health risks, and to formulate a program for dealing with these emissions.

The two agencies issued the results of their investigation in June 1986, in a report entitled "Energy From Waste". Among the conclusions of the report is that "... Based on the evaluations of the impact of waste incineration on health and the environment, the conclusion is that such incineration is an acceptable method of treating household and industrial waste" ("Energy from Waste," Statens energiverk and Naturvardsverket, 1986, p. 18). This conclusion was conditional based on implementing measures to restrict the emissions from existing and future plants. The report formed the basis of the government's decision that the moratorium not be extended, that the permitting of new waste-to-energy facilities be allowed, and that the Environmental Protection Agency work to ensure that existing facilities be modified as necessary to comply with the guidelines recommended in the joint report by no later than 1991 . The agency reviewed all existing licenses and revised the conditions as necessary to comply with the guidelines contained in the report. Current permit limits for dioxins and furans (in EADON TCDD equivalents) range from 0.1 to $2 \mathrm{ng} / \mathrm{m}^{3}$.

The Environmental Protection Agency issued a report in 1988 entitled "Solid Waste and Environment." This report established a strategy to meet certain goals in terms of protecting health and the environment, saving natural resources, fostering sound economic development, protecting strategic materials, and eliminating litter. The strategy proposed included:

- minimizing using dangerous materials in products;

- ensuring proper collection, treatment, and disposal of those dangerous materials that are unavoidable;

- minimizing the production of waste;

- recycling as much as is economically and technically possible; and

- treating the remaining waste in an environmentally sound manner.

In May 1990, the Swedish Parliament approved a waste management program. The overall objective of the program was to:

- restrict the volume and content of hazardous substances in waste; 
- increase recycling and reuse; and

- improve techniques for managing the wastes which cannot be avoided, reduced, recycled, or reused.

Among the key provisions of this program were:

- Waste is a burden upon the environment. Producers will be responsible for waste that arises as a result of production, including a cost responsibility.

- Products must be clean. The hazardous material content of products and waste must be considerably reduced by substituting less hazardous materials and thoroughly testricting the use of chemicals and materials which are hazardous to the health and the environment.

- The large volumes of waste must be reduced. Reuse and recovery must increase.

The Waste Bill of 1990 included various provisions to expand the "producer pays" concept. The bill required municipalities to develop a specific waste plan; placed greater responsibility on industry and the commercial sector to provide municipalities with information; gave municipalities additional rights in terms of taking responsibility for other portions of the waste stream; established that source separation is to be implemented such that as of 1994 , no untreated, unseparated waste materials would be delivered to landfills; and emphasized the need for reducing and, in some instances, eliminating hazardous materials in products. The government also established a special council (AFR, Avfallsforskningsradet) to manage research on environmentally sound product development and waste management.

Recent legislation in Sweden has emphasized the concept of "producer responsibility." The eco-cycle bill, which passed in February 1993, and introduced into law in January 1994, seeks more efficient use of materials and resources of the country by requiring greater participation by producers in the production, recovery, and reuse of waste. The bill identifies several categories of materials to which this principal may be applied, including packaging, electronics, electrical appliances, tires, plastics, and automobiles. Provisions of the bill shifts responsibility for collecting, treating, reusing, and disposing process residues from the public sector to manufacturers.

\section{Background}

Sweden has a total area of $449,964 \mathrm{~km}^{2}\left(173,732 \mathrm{mi}^{2}\right)$, including streams and nearly 100,000 ponds and lakes. Sweden is slightly smaller than California, and is located at approximately the same latitude as Juneau, Alaska. It shares a 1,619-km border with Norway, a $586-\mathrm{km}$ border with Finland, and has a 3,218-km coastline. Its closest neighbors across the Baltic Sea include Denmark, Germany, Poland, Latvia, Estonia, and Lithuania. Eighty-four percent of the population of approximately 8.6 million live in urban settings, with about $85 \%$ living in the southern third of the country. The average population density is $19 / \mathrm{km}^{2}\left(50 / \mathrm{mi}^{2}\right)$. The capital city, Stockholm, has a population of approximately 700,000 in the city proper ( 1.5 million when the surrounding region is included).

There are 24 counties and 286 municipalities in Sweden. In addition to Stockholm, Gothenburg, has a population of approximately 430,000 , and Malmo, has 230,000. Of the remaining 281 municipalities, 63 have less than 10,000 inhabitants, 180 have 10,000 to 50,000 , while 38 have 50,000 to 200,000 .

Sweden has a temperate climate in the south with cold winters, while the climate in the north of Sweden is sub-arctic. The terrain is mostly flat or gently rolling lowlands, with mountains to the west. The highest peak is Kebnekaise, $2,111 \mathrm{~m}(6,926 \mathrm{ft})$ above sea level. Sweden is $64 \%$ forest and woodland. 
The natural resources include forests, zinc, iron ore, copper, silver, and uranium. Sweden lacks any significant oil or coal deposits. Approximately $15 \%$ of its energy supply comes from hydropower. An estimated $50 \%$ of the energy consumed comes from imported oil, $7 \%$ from imported coal and coke, and $15 \%$ from 12 nuclear reactors (accounting for almost $50 \%$ of Sweden's electrical energy). A muchdebated law was passed in 1980 which requires phasing out nuclear units by 2010 . This issue continues to be discussed.

The industrialization of Sweden began in the 1870 s. Since then, Sweden has evolved from a primarily agrarian country to one in which less than $3 \%$ of the work force is employed in agriculture. Sweden's industry is based on its three most important natural resources-timber, iron ore, and hydropower. The industrial base includes iron and steel production; manufacturing precision tools, agricultural equipment, aircraft, automobiles, pollution control equipment, and other high-value-added engineered components; paper, pulp, and other wood products production; and chemicals, petroleum, and petroleum products processing. The engineering sector accounts for $50 \%$ of the industrial output. The Swedish economy is heavily oriented to foreign trade, with exports accounting for almost $50 \%$ of the gross domestic product in 1990 .

Sweden is a member of, among other organizations, the United Nations, the Organization for Economic Cooperation and Development, various Nordic organizations and, as of January 1, 1995, the European Union.

\section{Overview of Political and Judicial Structure}

Sweden is a constitutional monarchy, with a parliamentary form of government. In 1523, the kingdom of Sweden declared its independence from Danish nule. For the next 150 years, Sweden's influence grew. By the late 1600s, Sweden had become a major European power. In 1709, it suffered a military defeat at the hand of Russia and subsequently lost most of its European possessions. In 1809, a constitutional monarchy was established, giving most of the power to the king. Over the next century, the power of Parliament grew. In 1917, parliamentary rule was adopted. In 1975, the constitution reduced the role of the king to mainly ceremonial activities.

The powers of government are shared between national, regional, and local authorities. The Swedish national government consists of the Riksdag and the Parliament. Parliament's 349 members are elected directly by the people every three years. The most recent election was held in the fall of 1994 . A minimum of $4 \%$ of the vote is required to have representation in the Riksdag. The party holding the greatest number of seats in the Riksdag following each election forms the executive branch, which consists of a prime minister and 13 ministers. The ministers head the various ministries within the national government, whose main tasks relate to preparing legislation.

The Swedish legal system has been influenced by German, French, and to a lesser degree, Roman law. Sweden has not followed the large-scale codification models found in the Code Civil in France and in the German system. Written law, however, does play a greater role in Sweden than case law. Thus, the Swedish system can be categorized as being somewhere between the Anglo-American system of case law and the Franco-German approach, which relies on detailed codes. The process of lawmaking in Sweden generally begins with an initiative for legislation being proposed by the govemment, professional or trade unions, government agencies, or at the request of the Riksdag itself. The sponsoring ministry appoints a commission of inquiry to prepare a report on the proposed legislation. The results and recommendations of the commission are then examined by the legislative department of the ministry concerned, which also solicits comment from affected stakeholders and other interested parties. Public comment is also part of this process. If the decision is to proceed with the legislation, a bill is drafted. The bill is forwarded to 
the Council on Legislation, a body composed of justices of the Supreme Court and the Supreme Administrative Court, the highest judicial and administrative authorities in Sweden.

Upon incorporation of the Council's comments, a proposed bill is forwarded to the Riksdag for approval. The approval process in the Riksdag generally involves referring of a proposed bill to applicable standing committees for review, amendment, approval, and forwarding to a plenary session of the Riksdag as a bill. The commission of inquiries report and the Council's opinion, along with the Riksdag conmittee report, are all printed and distributed and become an important part of the record used to interpret the intent of the legislation. Thus, it is not unusual to find concise, brief wording in the actual legislation, because the nuances have been addressed during the process and reflected in the various reports and opinions that are part of the bill's record.

The judicial branch of the Swedish government consists of a general court system and an administrative court system. The generai court system hears cases related to civil law and criminal law, as well as some administrative matters such as property transfers, probate, land development, etc. The administrative courts hear cases related to decisions made by public authorities. Each system has three levels-the district courts, the intermediate courts of appeal, and the Supreme Court.

\section{The General Court}

There are approximately 100 district courts. The district courts play a dominant role in administering Swedish law. All criminal and civil cases start at the district level. The bench for most criminal cases and in some family law cases is comprised of one judge, assisted by a group of lay people who are elected for three-year terms. Each lay assessor is on duty for a period of 10 days per year. They participate in the verdict process, but not as a jury. Rather, they deliberate as a committee, with the judge acting as chairman.

About $10 \%$ of the district court cases are referred to the court of appeals. There are six courts of appeal. Cases are usually heard by three or four judges or three judges and two lay assessors.

The Supreme Court, which consists of five judges, can hear appeals against decisions of the lower court of appeals. Generally, the Supreme Court hears cases with significant precedent-setting potential.

\section{The Administrative Court}

The administrative court system is in place to ensure that the public administration performs its activities in accordance with the laws. The administrative courts will hear cases related to taxation, or appeals of decisions made by local authorities on matters such as assessments or placement of children in foster care. The decisions of the administrative courts can be appealed to the administrative appeals court. There are four such courts in Sweden. Appeals to decisions of the appeals court in cases of significance are heard by a five-judge Supreme Administrative Court.

\section{Agencies, Counties, and Municipalities}

There are approximately 100 central administrative agencies, 24 county administrations, and, since January 1992, 286 municipal districts which are involved in environmental management in Sweden. The counties have a popularly elected council which has the power to levy an income tax and is generally responsible for health and medical care, as well as zoning and environmental protection. Each county authority has a special unit for dealing with environmental issues, particularly those relating to the Nature Conservancy Act and the Environmental Protection Act. 
The municipal districts each have a popularly elected council, can also collect an income tax, and operate public services such as schools, child and old age care facilities, utilities, housing, and cultural and leisure programs. Municipalities, through their environmental and health protection administrations, are responsible for environmental protection at the local level. Since 1972, as a result of the public cleansing act, municipalities have been responsible for collection and transport of domestic waste. The revised Cleansing Act of 1980 assigned to municipalities the responsibility for ensuring that treatment plants for domestic wastes are available.

\section{Overview of Environmental Policy}

\section{History}

Environmental regulation in Sweden has a long history, beginning in the 1960s. The first major piece of legislation was the Nature Conservancy Act, passed in 1964. In 1967, the Environmental Protection Agency was established. In 1968, the Environmental Advisory Committee was established to act as a government consultant in environmental affairs. In 1968, the government also introduced an act limiting the sulfur content of heavy fuel oil. In 1969, the Environment Protection Act was passed. This, along with the Act on Products Hazardous to Health and the Environment, passed in 1973, form the key legislative structure for regulating the protection of the environment in Sweden.

Major modifications were made to the existing environmental legislation in Sweden in 1988, when significant comprehensive legislation establishing new ordinances and amendments to existing laws were passed. These amendments and ordinances addressed acid rain, marine pollution, "greenhouse" gases, strengthened enforcement measures (including mandating prison sentences), and environmental insurance requirements.

In May 1990, the Swedish Parliament approved a waste management program. The overall objective of the program was to:

- restrict the volume and content of hazardous substances in waste,

- increase recycling and reuse, and

- improve the techniques for the management of the wastes which cannot be avoided, reduced, recycled, or reused.

Among the key provisions of this program were:

- Waste is a burden upon the environment. The producers will be responsible for waste that arises as a result of production, including a cost responsibility.

- Products must be clean. The hazardous content in products and waste must be considerably reduced by substitution of less hazardous materials and through restricting the use of chemicals and materials which are hazardous to the health and the environment.

- The large volumes of waste must be reduced. Reuse and recovery must increase.

Each industry, with an activity resulting in waste production, is required to report the amount of waste and its content to local authorities. 
Since January 1991, every municipality is obligated to prepare a "solid waste plan" for handling all wastes produced in the municipality, including domestic waste, industrial waste, hazardous waste, hospital waste, etc. An inventory of the source and amount of wastes is also required.

The federal government also gave municipalities the right to extend their responsibility for the collection, transportation, and treatment of domestic waste to other waste stream components.

Since 1994, the goal has been to essentially cease the incineration and landfilling of unseparated waste. Methane gas from landfills will be recovered as energy or flared.

The key provisions of the Nature Conservancy Act, the Environmental Protection Act and Ordinance, and the Act on Products Hazardous to Health and the Environment are described later in this report.

\section{Key Organizations}

The approach in Sweden is to use various licensing and permitting processes, planning activities, surveillance measures, and sanctions to protect environment. In addition, Sweden also employs economic instruments to encourage environmentally desirable behavior. For example, it levels taxes on $\mathrm{CO}_{2}, \mathrm{NO}_{\mathrm{x}}$, and sulfur emissions, as well as a differential tax on diesel fuel, to stimulate using environmentally superior grades of diesel fuel.

The responsibility for enforcing environmental laws is distributed among the national government, the regional authorities, and the local municipalities themselves.

The key central government authority responsible for environmental protection in Sweden is the Environmental Protection Board (Agency), Naturvardsverket. However, the majority of the decisions that effect the environment are made by other bodies, including the Parliament, the Franchise Board for Environment Protection, the Products Control Board, and county and local administrations. The agency uses indirect means of control and influence, through cooperative efforts with other organizations, issuing general recommendations and regulations, consulting, and research and education. The agency, for example, is required to comment on license applications submitted to the Franchise Board. In the case of waste management facilities, the agency has issued guidance on allowable emission limits, which are then required to be incorporated into individual permits for each facility.

The agency is responsible for executing the decisions of the government, monitoring new technological developments, and proposing recommended changes to environmental regulations. The agency's responsibilities include environmental protection matters under the Environmental Protection Act (except where the Act specifically places responsibilities on other bodies), product control (the Product Control Board is attached to the Environmental Protection Agency and is responsible for matters arising under the Acts on Products Hazardous to Health and the Environment), nature conservation, outdoor recreation, and research.

The major authorities and bodies with which the Environmental Protection Agency consults and cooperates include the National Board of Occupational Safety and Health, the National Labor Market Board, the Delegation for the Coordination of Marine Resource Activities, the Swedish Forest Service, NUTEK (an organization charged with adapting Sweden's energy supply system to environmental and resource conservation requirements), the National Board of Fisheries, the National Board for Consumer Policies, the National Board of Agriculture, the National Land Survey Administration, the National Food Administration, the National Board of Physical Planning and Building, the Central Board of National Antiquities, the National Administration of Shipping and Navigation, the National Board of Forestry, the 
National Board of Health and Welfare, Statistics Sweden, and the National Institute of Environmental Medicine, among others.

The key organizations which have major roles in the development, passage, implementation, and enforcement of environmental regulations in Sweden are delineated in Table 1, with a brief summary of their respective roles in the process of developing, refining, and implementing environmental regulations.

Table 1. Key Organizations Involved in Implementing Environmental Regulations in Sweden

\begin{tabular}{|c|c|c|}
\hline Organization & Description & Role \\
\hline Ministry of the Environment & $\begin{array}{l}\text { Established in 1987; overall responsibility for } \\
\text { environmental affairs. }\end{array}$ & $\begin{array}{l}\text { To prepare legislation; respond to questions on } \\
\text { the legislation; engage in international cooperation } \\
\text { and agreements effecting the environment, natural } \\
\text { resources, nature conservation, radiation } \\
\text { protection, and water. }\end{array}$ \\
\hline $\begin{array}{l}\text { National Environmental } \\
\text { Protection Agency }\end{array}$ & $\begin{array}{l}\text { An independent agency, in place since } 1970 \text {, } \\
\text { comprised of the Administrative Department, the } \\
\text { Natural Resources Department, the Technical } \\
\text { Department, the Research and Development } \\
\text { Department, the Emission and Product Control } \\
\text { Laboratory, the Products Control Board, and the } \\
\text { Research Council. }\end{array}$ & $\begin{array}{l}\text { To implement Parliamentary and government } \\
\text { environmental policy, monitor developments, and } \\
\text { make proposals to the government related to } \\
\text { improving the environment. The board manages } \\
\text { the environmental protection research program } \\
\text { and the environmental monitoring program. }\end{array}$ \\
\hline $\begin{array}{l}\text { National Franchise Board } \\
\text { for Environmental Protection }\end{array}$ & $\begin{array}{l}\text { Central government agency that examines permit } \\
\text { applications for major sources. }\end{array}$ & $\begin{array}{l}\text { Structured like a court of law, the Board, along } \\
\text { with County Administrations, hears cases under } \\
\text { the Environment Protection Act and is the issuing } \\
\text { anthority for licenses and permits of major } \\
\text { facilities. }\end{array}$ \\
\hline $\begin{array}{l}\text { Central Administrative } \\
\text { Agencies }\end{array}$ & $\begin{array}{l}\text { Various organizations, including the National } \\
\text { Board for Consumer Policies, the National } \\
\text { Institute for Environmental Medicine, the National } \\
\text { Board of Health and Welfare, Statistics Sweden, } \\
\text { and NUTEK - the National Board for Industrial } \\
\text { and Technical Development (former Energy } \\
\text { Administration). }\end{array}$ & $\begin{array}{l}\text { To provide input from the respective stakeholders } \\
\text { perspective on issues related to planning, siting, } \\
\text { operation, occupational health and safety, product } \\
\text { hazards, environmental impacts, etc. }\end{array}$ \\
\hline County Administrations & $\begin{array}{l}\text { Administrative organizations within the governing } \\
\text { body of each of the } 24 \text { counties with } \\
\text { responsibility for various aspects of environmental } \\
\text { management. }\end{array}$ & $\begin{array}{l}\text { Regional supervisory authority under the } \\
\text { Environment Protection Act and the Health } \\
\text { Protection Act. They are, along with the Labor } \\
\text { Inspectorate, the supervisory authority under the } \\
\text { Act on Products Hazardous to the Health and to } \\
\text { the Environment. }\end{array}$ \\
\hline Municipalities & $\begin{array}{l}286 \text { municipalities, varying in size from less than } \\
3000 \text { to more than } 600,000 \text { residents. }\end{array}$ & $\begin{array}{l}\text { Local responsibility for nature conservation. The } \\
\text { municipal environment, building and health } \\
\text { protection committes directly impact local } \\
\text { environmental protection activities and act as } \\
\text { local supervisory authorities under the Health } \\
\text { Protection Act and the Act on Products Hazardous } \\
\text { to Health and the Environment, as well under the } \\
\text { Environmental Protection Act if the county } \\
\text { administration so delegates. Waste management is } \\
\text { generally carried out by local arthorities. }\end{array}$ \\
\hline
\end{tabular}




\section{Future Issues}

Sweden, along with Norway, Finland, and Austria, negotiated a four-year transition period during which these countries can retain their higher levels of environmental limits. This effectively deferred a major obstacle to Sweden's joining the European Union. It remains to be seen exactly what will occur at the end of the four years. One possibility is certainly that these countries will then be required to lower their standards to come into compliance with the applicable European Union standards. 


\section{Major Environmental Legislation}

The major pieces of general environmental legislation and legislation that specifically focuses on municipal waste management are summarized below. The history of environmental regulation in Sweden is long, beginning with the Nature Conservancy Act of 1964 and the Environmental Protection Act of 1969. Each of these Acts has been amended and modified, and additional laws have been passed over the course of about 30 years since the passage of the Nature Conservancy Act. In 1986, the Parliament approved a new Building and Planning Act and a new Natural Resource Act, which gave greater responsibility for planning and building matters to local authorities, while reserving the right of the county administration to intervene in areas impacting regional and national interests.

\section{Key Provisions of Major General Environmental Legislation}

\section{The Nature Conservancy Act (1964) and Nature Conservancy Ordinance (1976)}

The Nature Conservancy Act laid out the underlying guiding principles of preservation of Sweden's natural resources, plants, and animals. It contains provisions related to the establishment of national parks, and regulations aimed at protecting the countryside and providing the public with opportunities for enjoying nature. This Act established that the natural environment is an asset that requires and deserves protection and conservation. The Act established that both the national and regional authorities are responsible for protecting areas of natural interest and provides for their preservation as national parks, nature reserves, and conservation areas. The Act also contains provisions relating to endangered species protection, limitations on outdoor advertising, and prohibitions against littering. The county administration is the responsible authority under the Nature Conservancy Act, with the exception of the setting aside of lands for establishment of national parks, which is the responsibility of the government, with consent of the Riksdag. Like most legislation, this act requires that the county consult with the Environmental Protection Agency and the affected local municipalities prior to taking any action regarding the setting up of a nature reserve, conservation area, or taking any other major action relating to conservation issues. The ordinance describes in more detail specific aspects of the Act, including conditions under which endangered animals and plants may be imported and exported.

\section{The Environment Protection Act and Environment Protection Ordinance}

The Environment Protection Act, which came into force in 1969, as amended [including the Environment Protection Ordinance (1989)], governs environmentally hazardous activities. It established the legal basis upon which environmental protection is implemented in Sweden. It governs activities that are performed on a property or other permanent plant in which the operations are a source of disturbance to the neighborhood. Such disturbances include emission of water and air pollutants, vibration, light, or noise. The Act established licensing requirements for certain activities. The Act details specific notification and permitting requirements which are dependent upon the degree and extent of potential pollution emitted. Public participation is a key component of the license approval process.

For major pollutant sources, such as pulp mills and steel mills, permits must be obtained from the National Franchise Board for Environmental Protection. Less significant sources require licenses from county administration agencies. For facilities with limited and local impacts, no permission is required. However, such operations must notify the local environmental and health board.

The annex to the Environmental Protection Ordinance establishes a list of environmentally hazardous activities which require compulsory permits or reports. The annex also describes the responsible authority. The annex categorizes over 250 activities in various business sectors (i.e., agriculture, mining, 
manufacturing, public administration, and other services) into Categories A, B, and C. Category A items require that a permit be obtained from the National Franchise Board for Environmental Protection; Category $\mathrm{B}$ iterns require a permit from the county administrative board; and Category $\mathrm{C}$ items require that a report be submitted to the municipal environment and health committee.

In reviewing the lists, the responsible permitting authority is determined generally based upon the nature of the process, the degree of hazardousness and, in some cases, the quantity of emissions expected. For example, under manufacturing, a dairy facility which expects to discharge more than 5,000 tons per annum of whey is a Category B facility, thus requiring a permit from the county administrative body. A similar facility which expects to discharge no more than 5,000 tons per annum of whey is a Category $\mathrm{C}$ facility and is required to file a report with the municipal authority. A factory that produces ammonia requires a permit from the Franchise Board, regardless of the production capacity. A metal refinery that produces more than 3,000 tons per annum is a Category A facility, while a metal refinery that produces a maximum of 3,000 tons is a Category B facility.

The responsible authority for waste management facilities (categorized under cleaning, sweeping, and sanitation in the Public Administration and other services section) is based upon the quantity of waste handled. For a facility that stores or treats waste from households, hospitals, industry, purification plants, or similar facilities processing in excess of 75,000 tons per annum, a permit must be obtained from the Franchise Board (i.e., Category A). For a facility processing in excess of 50 tons but not more than 75,000 tons, the permit must be obtained from the county. For facilities processing less than 50 tons per year, no permit is required. However, a report must be filed with the municipal health and environment committee.

A party intending to construct and operate a waste management facility is required to submit a written request to the applicable authority. If it is to the National Franchise Board, the board is required to notify the Environment Protection Agency, the county, and the local authorities concerned, and must publish a notice of the application in the local press. The board also solicits comments from other national authorities. Meetings with concerned parties are part of the licensing process.

Anyone intending to engage in an environmentally hazardous activity is required to choose a site where the impacts of such activities can be minimized, and to take other reasonable precautions to protect the environment. The basis for determining what is reasonable is what is technologically feasible, economically reasonable, and economically justified. The Environmental Protection Act includes provisions which require that anyone nunning such an environmentally hazardous operation must comply with the conditions imposed in the permit. These include safety measures, operating limits, and emergency response. Such conditions are generally in force for 10 years. However, permit limits and conditions can be modified during the 10-year period in the event of unforeseen changes in the emissions from the facility, significant changes in the conditions of the surrounding area, or new technology being available which can substantially improve the level (or monitoring) of emissions from the facility.

Each environmentally hazardous activity is under the supervision of a responsible authority. The responsible authority can be the municipality's environment and health protection committee, the county administrative board, or the National Franchise Board for Environmental Protection. In each instance, under the provisions of the Environmental Protection Act, the supervisory authority has the right of access and the right to carry out necessary monitoring and checks. The operating parties are required to submit to the responsible authority such information as is required by the supervising authority. An annual report to the county or municipal authorities is required of each party conducting environmentally hazardous operations. This report must describe the measures taken during the year to comply with the permit requirements and the results obtained. 
If operating problems arise at a permitted facility, the supervisory authorities first try to resolve issues on a voluntary basis. They can, if necessary, issue injunctions or fines. If warranted, the Environmental Protection Agency can demand a special investigation by the Franchise Board. The polluting activity may then be prohibited or additional protective measures specified. Anyone who does not comply with the requirements of the Environmental Protection Act or its related directives is liable for fine or up to two years imprisonment. In addition, anyone disregarding regulations may be subject to a penalty equal to any profit resulting from their failure to comply.

\section{The Act on Products Hazardous to Health and to the Environment}

The Act on Products Hazardous to Health and to the Environment (1973), which superseded the earlier Poisons Ordinance, Pesticides Ordinance, and PCB Act, provided for stricter controls over materials, which, because of their chemical or physical properties, constitute a hazard to health or the environment. The Act includes a requirement that anyone handling such materials do so in a proper manner to ensure that all necessary precautions are taken to prevent any harmful effects. The Act also requires that the producer or importer of materials thoroughly investigate the health and environmental properties of materials to ensure that adequate safety precautions are taken if needed. The Act gave the authority to the Product Control Board to intervene, if necessary, in the interest of protecting the environment. The various measures available to the board include licensing requirements or prohibitions on handling or importing substances where this is determined desirable.

The Ordinance on Products Hazardous to the Health and to the Environment, also issued in 1973, contained more detailed sections addressing specific products, including poisons, pesticides, PCB, gasoline, and cadmium. Pursuant to the Act and Ordinance, the Product Control Board has issued more detailed regulations targeting specific products, such as batteries.

Since 1987, all Swedish municipalities have taken part in a campaign to collect small batteries. In addition, the government imposed a ban on the sale of certain alkali batteries and an obligation to print warnings on other batteries. The government has also instituted a ban (with certain exceptions) in using cadmium in such things as plastics and paints.

\section{The Environmental Damage Act}

The Environmental Damage Act, passed in 1986, governs claims for indemnity for environmental damage. This Act addresses compensation for personal injury and for pure financial loss caused to the surroundings by operations performed on real property. The Act covers injury or damage caused by: (1) pollution of water courses; (2) pollution of groundwater; (3) changes in groundwater level; (4) air pollution; (5) soil pollution; (6) noise; and (7) vibration or other similar disturbances. The Act requires that there be a substantial probability of a causal connection based upon the nature of the disturbance, other possible causes of the damage, and other circumstances, and that damages or injury not caused by willful or negligent acts shall be payable only if the disturbance causing the damage or injury "is not admissible with regard to local conditions." There are limits to the amount payable to each person and by each company (about $\$ 900,000$ per person and $\$ 35$ million for a company).

\section{The Act on Chemical Products}

The Act on Chemical Products, passed in 1986, requires that manufacturers or importers perform a risk assessment to serve as a basis for precautionary measures, such as labelling. Pursuant to this Act, manufacturers and importers are required to replace environmentally harmful materials with other materials less harmful when available. The National Chemicals Inspectorate regulates using chemicals in Sweden. 


\section{The Ordinance on Vehicle Exhausts}

The Ordinance on Vehicle Exhausts (1986) regulates emissions from automobiles. The Act requires that vehicles for the 1989 model year and beyond meet tougher standards, similar to those in place in the U.S.

\section{The Planning and Building Act}

The Planning and Building Act (1987) placed greater responsibility for planning at the regional and local level. In particular, it requires that all municipalities have in place a structure plan covering their entire area.

\section{The Natural Resources Act}

The Natural Resources Act, passed in 1987, contains basic regulations related to the conservation and development of natural resources, including special reguiations for certain environmentally sensitive areas, as well as regulations governing the review process related to certain industrial facilities.

\section{The Vehicle Scrapping Act and the Vehicle Scrapping Ordinance}

The Vehicle Scrapping Act and the Vehicle Scrapping Ordinance (1975) establish a system of compensation to owners of vehicles who can provide evidence that their car has been properly disposed of.

\section{Key Provisions of Major Legislation Specific to Solid Waste Management}

\section{The Cleansing Act and the Cleansing Ordinance}

The first public Cleansing Act was issued in 1972, placing responsibility for collection and transport of domestic waste on municipalities. The revised Act of 1979 also placed the responsibility for ensuring waste treatment on municipalities. The Act and Ordinance provide the framework for domestic waste management in Sweden. It is left to each municipality, with guidance from the Environmental Protection Agency and the county administrations, to establish their own public cleansing acts specifically addressing the management of domestic and other wastes in their jurisdictions. Pursuant to the Act, the costs of the municipal waste management system are to be covered via a special fee for each household or homeowner.

The Environmental Protection Agency issued a report in 1988 entitled "Solid Waste and Environment." This report established a strategy to meet certain goals: protection of health and the environment; savings of natural resources; fostering sound economic development; protection of strategic materials; and elimination of litter. The strategy proposed included:

- minimizing the use of dangerous materials in products;

- ensuring proper collection, treatment, and disposal of those dangerous materials that are unavoidable;

- minimizing the production of waste;

- recycling as much as is economically and technically possible; and

- treating the remaining waste in an environmentally sound manner. 


\section{The Waste Bill}

In May 1990, the Swedish Parliament approved a bill reflecting the goais stated in 1988 . The bill incorporated the following:

- Waste is a burden upon the environment that producers must be responsible for, including a cost responsibility.

- Products must be as clean as possible, with the hazardous content in products and waste being reduced.

- Reusing and recovering materials from the waste stream must increase.

- Final treatment and disposal must be performed in an environmentally sound manner.

The Waste Bill of 1990 included various provisions to expand the "producer pays" concept. The bill implemented additional requirements in terms of municipal responsibility to provide a specific waste plan that details the sources of waste and its characteristics, and describes the collection, processing, treatment, and disposal methods to be used. The bill also gives municipalities additional rights in terms of taking responsibility for other portions of the waste stream. The bill, in turn, placed greater responsibility on industry and the commercial sector to provide the municipality with information regarding waste products being generated by their activities.

The Waste Bill also established that source separation is to be implemented such that, as of 1994, no untreated, unseparated waste materials would be delivered to a landfill.

The bill emphasizes the need for reduction and, in some instances, elimination of hazardous materials in products themselves. It identifies certain hazardous substances (e.g., cadmium, mercury, mercury compounds, arsenic, lead compounds, and organic tin compounds) that will be phased out or severely restricted. The bill also increases requirements for producers and importers regarding substituting less hazardous materials and paying greater penalties for failing to comply.

Finally, the bill contains provisions addressing returnable PET bottles and PVC, and establishes a committee to review revisions to the packaging tax.

The government also established a special council (AFR, Avfallsforskningsradet) to manage research on environmentally sound product development and waste management. AFR's mission is to develop a national program and strategy for a low-waste society, including developing and fostering programs designed to develop environmentally safe products with the potential for maximum reuse and minimal non-recyclable residues which can be safely disposed of. AFR is also directed to encourage interdisciplinary efforts nationally and internationally related to waste minimization and environmentally sound final treatment and disposal of residuals.

\section{Recent Legislation}

Recent legislation in Sweden has emphasized the concept of "producer responsibility." The Eco-cycle bill, which was passed in February 1993 and introduced into law in January 1994, seeks more efficient use of materials and the production resources of the country by requiring greater participation by producers in the production, recovery, and reuse of waste. The bill identifies several categories of materials to which this principal may be applied, including packaging, electronics, electrical appliances, tires, plastics, and 
automobiles. The provisions of the bill shift responsibility for collection, treatment, reuse, and disposal of process residues from the public sector to the producers and importers of packaging.

The first ordinance adopted by the government under the Eco-cycle bill is the Glass and Cardboard Packaging Ordinance. This is due in part to the fact that the infrastructure for collection, recovery, and recycling these materials is already in place in Sweden. Under the Ordinance, responsibility for the collection and processing or disposal of the materials is placed upon the packaging producer. 


\section{Regulation of Emissions from Waste-to-Energy Facilities}

Waste-to-energy facilities, depending upon their annual throughput capacity, fall into A, B, or C categories under the Environmental Protection Act. As previously indicated, facilities which process in excess of 75,000 tons per annum are required to obtain their license from the Franchise Board. Those that process less than 75,000 but greater than 50 tons per year are required to obtain their license from the county administration. The emission limits and operational requirements governing performance and testing of the facilities are described in the individual permits. The Environmental Protection Agency has issued guidelines relating to emission levels that each facility in Sweden is required to comply with. As described below, these guidelines were issued in 1987 and provide a five-year period to bring existing facilities into compliance. Table 2 details the waste-to-energy facilities in Sweden, their annual capacity, and responsible licensing authority. Table 3 provides the recommended emission limits set forth by the Environmental Protection Agency and the permit limits in place for several facilities. As indicated, each facility has its own set of limits.

\section{Moratorium on the Licensing of New Waste-to-Energy Facilities}

\section{History}

On February 13, 1985, the Swedish EPA issued a moratorium on constructing new municipal solid waste incinerators. This moratorium was because data indicated that municipal incinerators were a major source of dioxins in the environment and data from 1984 showed the presence of dioxins in adipose tissues and mothers' milk. This, coupled with the findings that dioxins were extremely toxic to laboratory animals, combined to raise significant public concern.

At the time of the moratorium, more than half of the domestic waste collected in Sweden was incinerated. During the 1970s and 1980s, waste-to-energy became common in Sweden. This expansion was caused by the rapid rise in oil prices, the readily available market for energy sales to district heating systems, and governmental policy fostering the use of domestic alternative energy sources. Because municipalities were responsible for both domestic waste collection and for the district heating systems, implementing of wasteto-energy facilities servicing the district heating systems was greatly simplified. Thus, during the 1970s and early 1980s, 15 new facilities were constructed.

Polychlorinated dibenzodioxins and polychlorinated dibenzofurans are part of a family of halogenated aromatic hydrocarbons. This family also includes polychlorinated biphenyls. The chlorinated dibenzodioxins and dibenzofurans are commonly referred to as dioxins. Dioxins are chemically stable and break down slowly in the natural environment. Included in the dioxin family are some of the most toxic compounds identified. There are 210 different chemical compounds included in the family of dioxins75 paradioxins and 135 dibenzofurans. These compounds have similar tricyclic aromatic hydrocarbon structures and similar chemical characteristics. The toxicity and biological properties, however, do differ significantly, in some instances by several orders of magnitude.

Because of the possible environmental impacts of uncontrolled emissions of polychlorinated dibenzo-p-dioxins (PCDDs) and polychlorinated dibenzofurans (PCDFs) from various thermal processes, these compounds have received and continue to receive considerable attention. Among the various processes which emit these compounds are chlorination processes, such as manufacturing bleached pulp and paper that use chlorine, chemical manufacturing processes that involve the production of chlorinated compounds such as chlorinated phenols, herbicides, and catalysts; combustion processes such as municipal solid waste, sewage sludge, hospital waste, and 
Table 2. Incineration Plants in Sweden April 1992

\begin{tabular}{|c|c|c|c|}
\hline Location & $\begin{array}{l}\text { Capacity } \\
\text { (tons/yr) }\end{array}$ & Flue Gas Cleaning & $\begin{array}{c}\text { Responsible Licensing } \\
\text { Authority }\end{array}$ \\
\hline Avesta & 45,000 & wet, dry, ff & county \\
\hline Bollmora & 10,000 & dry, ff & county \\
\hline Bollnas & 20,000 & dry, ff & county \\
\hline Borlange & 20,000 & wet, esp & county \\
\hline Eksjo & 5,000 & wet & county \\
\hline Goteborg & 300,000 & wet, esp & Franchise Board \\
\hline Halmstad & 80,000 & wet, esp & Franchise Board \\
\hline Karlskoga & 35,000 & wet, wet, esp & county \\
\hline Karlstad & 50,000 & dry, ff & county \\
\hline Kiruna & 50,000 & wet & county \\
\hline Koping & 50,000 & dry, esp, ff & county \\
\hline Landskrona & 12,000 & dry, ff & county \\
\hline Lidkoping & 50,000 & dry, ff & county \\
\hline Linkoping & 200,000 & dry, ff & Franchise Board \\
\hline Malmo & 220,000 & dry, ff & Franchise Board \\
\hline Mora & 20,000 & dry, ff & county \\
\hline Stockholm & 220,000 & dry, ff & Franchise Board \\
\hline Sundsvall & 15,000 & dry, esp & county \\
\hline Umea & 100,000 & dry, ff & Franchise Board \\
\hline Uppsala & 250,000 & wet, dry, ff & Franchise Board \\
\hline Vastervik & 20,000 & dry, ff & county \\
\hline
\end{tabular}

ESP - electrostatic precipitator; FF - fabric filter; WET - wet scrubbing; DRY - dry scrubbing.

All wet scrubbers have a heat recovery system through flue gas condensation.

Source RVF, Swedish Waste Management Association and Bergstrom, Jan, "Flue Gas Cleaning in Sweden - Present Situation," Waste Management \& Research, 1993 II, 345-362. 
Table 3. Emission Limits for Various Waste-to-Energy Facilities

(Normalized at $10 \% \mathrm{CO}_{2}$, dry gas)

\begin{tabular}{|c|c|c|c|c|c|c|}
\hline $\begin{array}{l}\text { Facility - } \\
\text { Date of License }\end{array}$ & $\begin{array}{l}\text { Particulate } \\
\left(\mathrm{mg} / \mathrm{m}^{3}\right)\end{array}$ & $\begin{array}{c}\mathrm{HCl} \\
\left(\mathrm{mg} / \mathrm{m}^{3}\right)\end{array}$ & $\underset{\left(\mathrm{mg} / \mathrm{m}^{3}\right)}{\mathrm{CO}}$ & $\underset{\left(\mathrm{ug} / \mathrm{m}^{3}\right)}{\mathrm{Hg}}$ & $\begin{array}{l}\text { TCDD* } \\
\left(\mathrm{ng} / \mathrm{m}^{3}\right)\end{array}$ & $\mathrm{NO}_{\mathrm{x}}$ \\
\hline Swedish EPA Limits & 20 & 100 & 100 & $\begin{array}{l}80 \text { Existing } \\
\text { 30 Planning }\end{array}$ & $\begin{array}{l}2 \text { Existing } \\
\text { 0.1 New }\end{array}$ & \\
\hline Avesta - 11/12/87 & 20 & 100 & 100 & 80 & 2 & \\
\hline Bollmora- 01/29/91 & 20 & 100 & 500 Max. & 80 & 0.5 & $\begin{array}{c}400 \mathrm{mg} / \mathrm{m}^{3} \\
\mathrm{NO}_{2}\end{array}$ \\
\hline Bollnas - 12/01/91 & 20 & 100 & 100 & 80 & 2 & \\
\hline Borlange - 10/08/90 & 20 & 100 & $\begin{array}{l}300-4 \text { Straight } \\
15 \text { Min. Avg. }\end{array}$ & 80 & 2 & \\
\hline Eksjo - 07/22/88 & 20 & 100 & 100 & 80 & 2 & $\begin{array}{c}400 \mathrm{mg} / \mathrm{m}^{3} \\
\mathrm{NO}_{2} \\
\end{array}$ \\
\hline Goteborg - 04/17/90 & 10 & 20 & 100 & 30 & $\begin{array}{c}.5 \\
0.1-\text { Target }\end{array}$ & $\begin{array}{c}50 \mathrm{mg} / \mathrm{Mj} \\
\mathrm{NO}_{\mathrm{x}}\end{array}$ \\
\hline Halmstad - 07/09/87 & 20 & 100 & 100 & 30 & 0.5 & $\begin{array}{c}300 \mathrm{mg} / \mathrm{m}^{3} \\
\mathrm{NO}_{2}\end{array}$ \\
\hline Karlskoga - 08/02/89 & 20 & 100 & 100 & 30 & 0.1 & $\begin{array}{c}200 \mathrm{mg} / \mathrm{Mj} \\
\mathrm{NO}_{2} \\
\end{array}$ \\
\hline Karlstad - 08/27/87 & 20 & 100 & & 80 & 0.5 & \\
\hline Kiruna - 03/28/90 & 20 & 100 & 100 & 80 & 2 & \\
\hline Koping - 05/23/90 & 20 & 100 & & 80 & 2 & \\
\hline Landskrona - 10/14/93 & 20 & 80 & 200 & 10 & 0.3 & $\begin{array}{c}200 \mathrm{mg} / \mathrm{Mj} \\
\mathrm{NO}_{2}\end{array}$ \\
\hline Lidkoping & 20 & 100 & 100 & 80 & 0.3 & \\
\hline
\end{tabular}




\begin{tabular}{|c|c|c|c|c|c|c|}
\hline $\begin{array}{l}\text { Facility - } \\
\text { Date of License }\end{array}$ & $\begin{array}{l}\text { Particulate } \\
\left(\mathrm{mg} / \mathrm{m}^{3}\right)\end{array}$ & $\begin{array}{c}\mathrm{HCl} \\
\left(\mathrm{mg} / \mathrm{m}^{3}\right)\end{array}$ & $\begin{array}{c}\mathrm{CO} \\
\left(\mathrm{mg} / \mathrm{m}^{3}\right)\end{array}$ & $\underset{\left(\mathrm{ug} / \mathrm{m}^{3}\right)}{\mathrm{Hg}}$ & $\begin{array}{l}\text { TCDD* } \\
\left(\mathrm{ng} / \mathrm{m}^{3}\right)\end{array}$ & $\mathrm{NO}_{\mathrm{x}}$ \\
\hline Malmo - 09/19/86 & 25 & 150 & 150 & $\begin{array}{l}.25 \mathrm{~g} / \mathrm{ton} \\
\text { Input Waste }\end{array}$ & & \\
\hline Mora & 20 & 100 & 100 & 30 & 0.1 & \\
\hline Stockholm - 06/30/87 & 20 & 100 & 100 & 80 & 2 & \\
\hline Sundsvall - 11/29/90 & 20 & 100 & 100 & 80 & 2 & \\
\hline Umea - 11/02/89 & 20 & 100 & 100 & 40 & 0.5 & $\begin{array}{c}.55 \mathrm{~kg} / \mathrm{MW} \\
\mathrm{h} \\
\mathrm{NO}_{2} \\
\end{array}$ \\
\hline Uppsala - 12/28/89 & 10 & 100 & 100 & 30 & $\begin{array}{l}0.5 \text { Thru ' } 94 \text {, } \\
\text { then } 0.1\end{array}$ & $\begin{array}{c}.1 \mathrm{~g} / \mathrm{MJ} \\
\mathrm{NO}_{2} \\
\end{array}$ \\
\hline Vastervik - 04/27/90 & 20 & 100 & & 80 & 2 & \\
\hline $\begin{array}{l}\text { Linkoping - } 10 / 08 / 85 \\
\text { Rev. 01/14/92 }\end{array}$ & 20 & 100 & 100 & 80 & 0.3 & \\
\hline
\end{tabular}

*TCDD Toxic Equivalents based on EADON equivalents. Caution is required in comparing emission limits for various pollutants across countries, as testing methods, sampling protocols, and testing frequency vary and will affect results obtained.

Source: RVF, MALMO. 
industrial waste incineration; automobile engines; and high-temperature metal processing operations, such as ferrous and non-ferrous smelting and refining operations.

To account for the dramatic differences in toxicity among the various compounds, scientists have developed an approach which is based on comparing the toxicity of a given compound with the toxicity of 2-,3-,7-,8-TCDD, the most toxic member of the dioxin family. Toxic equivalents represent a methodology for calculating the toxic effect of combinations of more than 200 different compounds which comprise dioxin. The effects of the applicable homologues are compared to the toxic effect of TCDD to determine the toxic equivalent factor. A substance that is 1/10th as toxic as TCDD will have a toxic equivalence of 0.1 . There are several sets of equivalence factors developed by various organizations. Differences in the factors are attributable to differences in risk assessment methodologies, consideration of different pathways, etc. Table 4 details several alternative toxic equivalence factors. Sweden uses the EADON scale. This is subject to change as pressure for unifying of testing regimens increases among the Scandinavian and European Union countries.

Over the past decade, significant reductions in the levels of dioxin compounds emitted from various sources have been realized as a result of changes in operating conditions and process modifications. In Sweden in 1992, Dr. Rappe of Umea University estimated that changes implemented, including revising to the emission standard for municipal waste combustors, resulted in a reduction in dioxin emissions from 400 to $600 \mathrm{~g}$ (toxic equivalents) per year in 1985 to 100 to $200 \mathrm{~g}$ (toxic equivalents) per year in 1991 .

\section{Lifting the Moratorium}

In May 1985, the government assigned the then-National Energy Administration and the Environmental Protection Agency the task of investigating engineering requirements and emission limits that should be imposed on waste incineration. In November 1985, a research group was formed within the National Environmental Protection Board to investigate the issue of dioxin emissions from municipal waste incinerators, to correlate these emissions with potential health risks, and to formulate a program for dealing with these emissions. The research group drew upon the expertise of other organizations, including the National Institute of Environmental Medicine, which evaluated the health risks associated with dioxins and other pollutants.

The two agencies issued the results of their investigation in June 1986, in a report entitled "Energy from Waste." This report included sections addressing waste and its impact on the environment, energy recovery from waste, using waste as a fuel, the status of waste-to-energy technology, slag and ash residues, and recommendations regarding the future of waste incineration. It included evaluations of the energy conterit of waste, discussion of various emissions (including dioxins), health and environmental risks posed by different treatment approaches, characteristics of residuals, and recommendations regarding future emission limits. In addition, the report addresses disposing slag and ash from waste-to-energy facilities.

The agencies recommended that slag (bottom ash) and fly ash be deposited separately and that household waste not be deposited with bottom ash. They recommended that the disposal site be designed to the same standards that apply to disposing residue from other solid fuels (e.g., coal and wood). These requirements include that the site be covered with a barrier material, a drainage layer, and a cover of one meter of rock, gravel, or sand covered by vegetation.

Among the conclusions of the report is that "... Based on the evaluations of the impact of waste incineration on health and the environment, the conclusion is that such incineration is an acceptable method of treating household and industrial waste" ("Energy from Waste," Statens energiverk and Naturvardsverket, 1986, p. 18). This conclusion was dependent on implementing measures to restrict the emissions for existing and future plants to the limits delineated in the report and as summarized in Table 5. 
Table 4. Toxic Equivalent Factors

\begin{tabular}{|c|c|c|c|c|}
\hline Compound & $\begin{array}{l}\text { NATO } \\
\text { Factors } \\
\end{array}$ & EPA Factors & $\begin{array}{c}\text { EADON } \\
\text { Factors }\end{array}$ & TA LUFT \\
\hline 2378-Tetra CDD & 1 & 1 & 1 & 1 \\
\hline 12378-Penta CDD & 0.5 & .5 & 1 & 0.5 \\
\hline 123478-Hexa CDD & 0.1 & .04 & .03 & 0.1 \\
\hline 123678-Hexa CDD & 0.1 & .04 & .03 & .1 \\
\hline 123789-Hexa CDD & 0.1 & .001 & .03 & 0.1 \\
\hline 1234678-Hepta CDD & 0.01 & 0 & 0 & 0.01 \\
\hline Octa CDD & 0.001 & 0 & 0 & 0.001 \\
\hline 2378-Tetra CDF & 0.1 & 0.1 & 0.33 & 0.1 \\
\hline 12378-Penta CDF & 0.05 & 0.1 & 0.33 & 0.5 \\
\hline 23478-Penta CDF & 0.5 & 0.1 & 0.33 & 0.5 \\
\hline 123478-Hexa CDF & 0.1 & 0.01 & 0.01 & 0.1 \\
\hline 123678-Hexa CDF & 0.1 & 0.01 & 0.01 & 0.1 \\
\hline 123789-Hexa CDF & 0.1 & 0.01 & 0.01 & 0.1 \\
\hline 234678-Hexa CDF & 0.1 & 0.01 & 0.01 & 0.1 \\
\hline 1234678-Hepta CDF & 0.01 & 0.001 & 0.001 & 0.01 \\
\hline 1234789-Hepta CDF & 0.01 & 0.001 & 0.001 & 0.01 \\
\hline Octa CDF & 0.001 & 0 & 0 & 0.001 \\
\hline Other Tetra CDD & 0 & 0.01 & 0.01 & - \\
\hline Other Penta & 0 & 0.005 & 0.01 & -- \\
\hline Other Hexa CDD & 0 & 0.0004 & 0.0003 & -- \\
\hline Other Hepta CDD & 0 & 0.00001 & 0.00001 & - \\
\hline Other Tetra CDF & 0 & 0.001 & 0.003 & -- \\
\hline Other Penta CDF & 0 & 0.001 & 0.003 & -- \\
\hline Other Hexa CDF & 0 & 0.0001 & 0.0001 & -- \\
\hline Other Hepta CDF & 0 & 0.00001 & 0.00001 & -- \\
\hline
\end{tabular}


Table 5. Recommended Emission Requirements

\begin{tabular}{|c|c|}
\hline Emission & Requirements \\
\hline Hydrogen Chloride & $\begin{array}{l}\text { Emissions should not exceed } 100 \mathrm{mg} / \mathrm{nm}^{3} \text { dry gas, } 10 \% \mathrm{CO}_{2} \text {, } \\
\text { calculated as a monthly mean value. }\end{array}$ \\
\hline Mercury & $\begin{array}{l}\text { When inspected, emissions should not exceed } 0.08 \mathrm{mg} / \mathrm{nm}^{3} \mathrm{dry} \\
\text { gas, } 10 \% \mathrm{CO}_{2} \text {. As product control measures are implemented, it } \\
\text { should be possible to reduce this value to } 0.03 \mathrm{mg} / \mathrm{nm}^{3} \text {. }\end{array}$ \\
\hline Particulate & $\begin{array}{l}\text { Emissions should not exceed } 20 \mathrm{ng} / \mathrm{m}^{3} \text { dry gas, } 10 \% \mathrm{CO}_{2} \text {, } \\
\text { calculated as a monthly mean value. }\end{array}$ \\
\hline Dioxins & $\begin{array}{l}\text { When inspected, emissions from existing plants should not exceed } \\
\text { a target value of between } .5 \text { and } 2.0 \mathrm{ng} / \mathrm{nm}^{3} \text { dry gas, } 10 \% \mathrm{CO}_{2} \text {. } \\
\text { The target value for newly constructed plants should be } 0.1 \mathrm{ng} / \mathrm{m}^{3} \\
\text { dry gas, } 10 \% \mathrm{CO}_{2} \text {. The dioxin values are TCDD equivalents } \\
\text { calculated in accordance with EADON's model and measured } \\
\text { during normal operations in conformity with recommendations of } \\
\text { the Nordic Dioxin Group.* }\end{array}$ \\
\hline \multicolumn{2}{|c|}{$\begin{array}{l}\text { The National Environmental Protection Agency, in reevaluating requirements, will impose the } \\
\text { customary provisions relating to good combustion, residue handling, dust control, noise control, etc. } \\
\text { Operating a waste incineration plant on a continuous basis, and in such a manner that high } \\
\text { combustion efficiency can be maintained throughout the operating period, should be a general } \\
\text { requirement. The carbon monoxide in the flue gas should not exceed } 100 \mathrm{mg} / \mathrm{nm}^{3} \text {. If there is a risk } \\
\text { that this value will be exceeded, the auxiliary fuel supply must be connected. }\end{array}$} \\
\hline
\end{tabular}

Source:"Energy from Waste," Statens energiverk, Naturvardsverket, 1986.

*Comparing limits between countries must be handled with care. Different countries have different test protocols, which can effect results. Thus, the numerical limits against which compliance is measured may not be directly transferrable.

Issued in 1987, the report formed the basis of the government's decision that the moratorium not be extended, the permitting of new waste-to-energy facilities be allowed, and that the Environmental Protection Agency work to ensure that existing facilities be modified as necessary to comply with the guidelines recommended in the joint report by no later than 1991. The agency reviewed all the existing licenses and revised the conditions as necessary to comply with the guidelines contained in the report. Although licenses are generally granted for 10 years, Clause 24 of the Environmental Protection Act allows the agency to modify existing permits under certain conditions. In its decision, the government stated that the agency should use that provision if needed to ensure that all facilities would comply with these guidelines by 1991 . The agency reviewed and revised the permit requirements to meet the guidelines. As a result of implementing the changes, emissions from waste-to-energy facilities in Sweden were reduced by as much as $95 \%$, as shown in Table 6. 
Table 6. Yearly Emissions from Waste Incineration - 1985 and 1991

\begin{tabular}{|l|c|c|c|c|}
\hline \multicolumn{1}{|c|}{ Parameters } & Units & $\begin{array}{c}\text { Emissions } \\
(1985)\end{array}$ & $\begin{array}{c}\text { Emissions } \\
(1991)\end{array}$ & $\begin{array}{c}\text { Percent } \\
\text { Reduction }\end{array}$ \\
\hline \hline Particulate & $\mathrm{T} / \mathrm{Yr}$ & 420 & 45 & -90 \\
\hline $\mathrm{HCl}$ & $\mathrm{T} / \mathrm{Yr}$ & 8,400 & 410 & -95 \\
\hline $\mathrm{SO}_{\mathrm{x}}$ & $\mathrm{T} / \mathrm{Yr}$ & 3,400 & 700 & -80 \\
\hline $\mathrm{NO}_{\mathrm{x}}$ & $\mathrm{T} / \mathrm{Yr}$ & 3,400 & 3,200 & -6 \\
\hline $\mathrm{Hg}$ & $\mathrm{kg} / \mathrm{Yr}$ & 3,300 & 170 & -95 \\
\hline $\mathrm{Cd}$ & $\mathrm{kg} / \mathrm{Yr}$ & 400 & 35 & -90 \\
\hline $\mathrm{Pb}$ & $\mathrm{kg} / \mathrm{Yr}$ & 25,000 & 720 & -97 \\
\hline $\mathrm{Zn}$ & $\mathrm{kg} / \mathrm{Yr}$ & 54,000 & 2,800 & -95 \\
\hline $\begin{array}{l}\mathrm{Dioxin}(\mathrm{TCDD} \\
\text { EADON Equiv.) }\end{array}$ & $\mathrm{g} / \mathrm{Yr}$ & 90 & 8 & -90 \\
\hline
\end{tabular}

Source: "National Information on the Environment," RVF, 1993. 


\section{Waste Generation, Collection, Processing, Treatment, and Disposal in Sweden}

\section{Generation}

Domestic waste (exclusive of reused and recovered materials such as bottles, cans, newspapers, and cardboard estimated at almost 400,000 tons in 1990) in Sweden totalled appropriately 2.7 million tons in 1990. This equates to approximately $320 \mathrm{~kg}$ per capita. Industrial waste totalled approximately 4.9 million tons, while hazardous waste totalled approximately 0.2 million tons. Figure 1 details the amount of waste collected for the years 1985 and 1990. The composition of domestic waste is 35 to $45 \%$ paper; 25 to $35 \%$ kitchen or garden waste; 8 to $10 \%$ plastic; 6 to $8 \%$ glass; 2 to $4 \%$ metal; 2 to $4 \%$ textile, leather, and rubber; $1 \%$ wood, and 6 to $8 \%$ miscellaneous.

\section{Collection}

Collecting waste is the responsibility of the municipalities. They or their agents, through contracts, collect all domestic waste generated in Sweden. Approximately one-third of the municipalities provide collection services themselves, while the balance contract with various private companies. On a tonnage basis, about $50 \%$ of the domestic waste generated in Sweden is collected by the municipalities directly, and $50 \%$ is collected by private contractors on behalf of the municipalities.

\section{Recycling}

\section{Paper}

Figure 2 summarizes paper recycling from 1985 to 1991 . The amount recycled grew from 240,000 to 355,000 tons. The percentage recycled increased from about 45 percent to more than 60 percent.

\section{Glass}

Figure 3 shows glass recycling from 1985 to 1991 . Glass recycling grew from about $15 \%$ (22,000 tons) in 1986 to more than $40 \%$ (57,000 tons) in 1991.

\section{Aluminum}

In 1982, as a result of Parliament mandating a recycling program for aluminum beverage cans, $A B$ Returpak was formed to run a deposit system. The deposit system was introduced on March 1, 1984. In 1992, approximately $85 \%$ of aluminum cans were recovered. In 1993, 800 million returnable cans were recovered, representing $92 \%$ of the total used.

\section{Processing, Treatment, and Disposal}

Sweden relies heavily on waste-to-energy facilities to process its MSW. More than $50 \%$ of the domestic waste (exclusive of recycled materials) in Sweden was processed at 21 waste-to-energy facilities in 1992, ranging in capacity from 5,000 to more than 300,000 tons per year. Figure 4 shows how household waste was treated from 1975 to 1992 . Landfill disposal fell from $65 \%$ in 1975 to approximately $45 \%$ in 1991 , while waste-to-energy grew from slightly less than one-third to more than $50 \%$. There were an estimated 


\section{FIGURE 1 \\ WASTE COLLECTED \\ 1985 AND 1990}

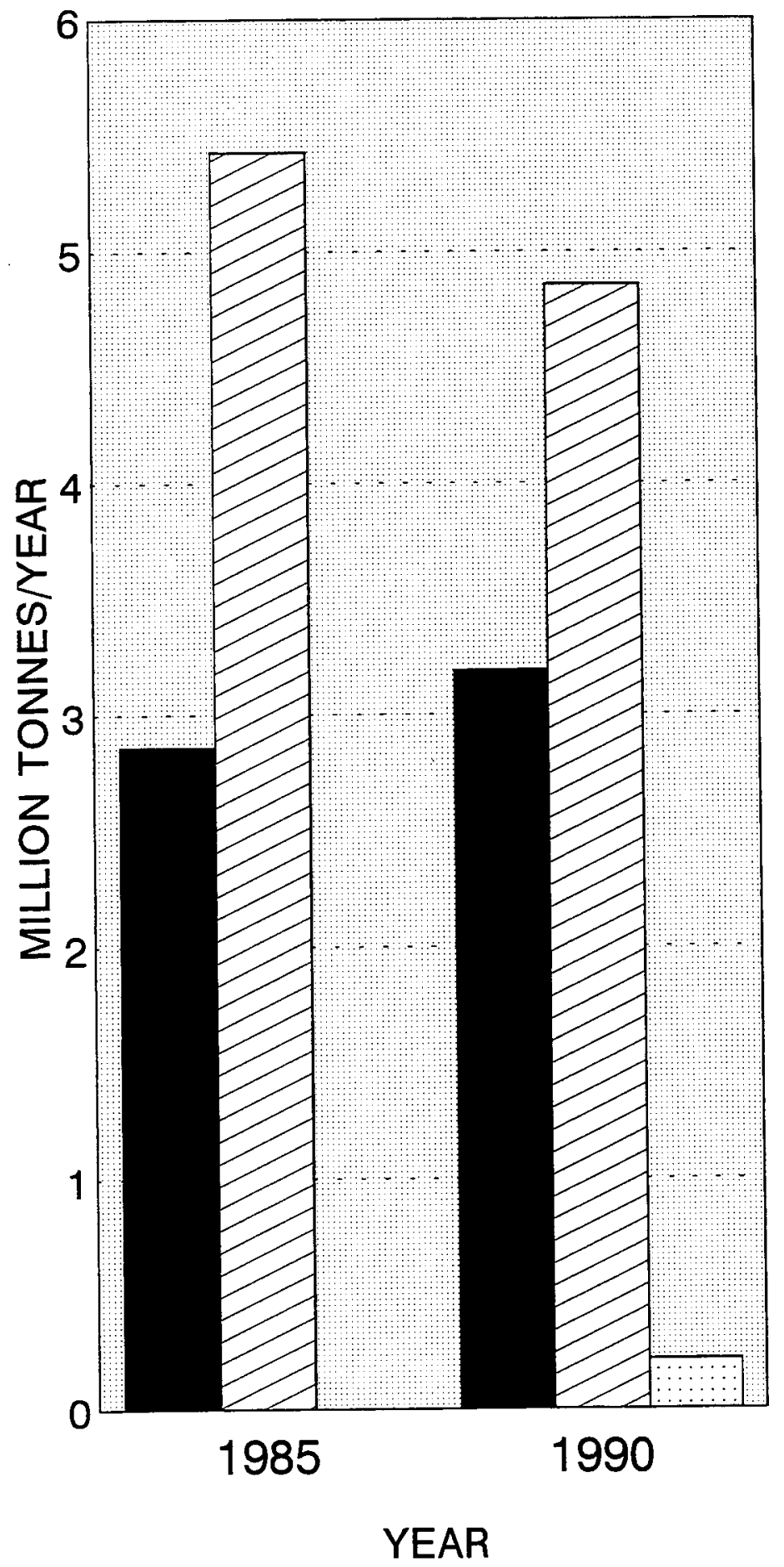

Hhld Waste (inc. Recy)

$\triangle$ Industrial Waste

Hazard. Waste

Source: "The Swedish Environment," 1994 


\section{FIGURE 2 \\ PAPER RECOVERY}

(News and Journals)

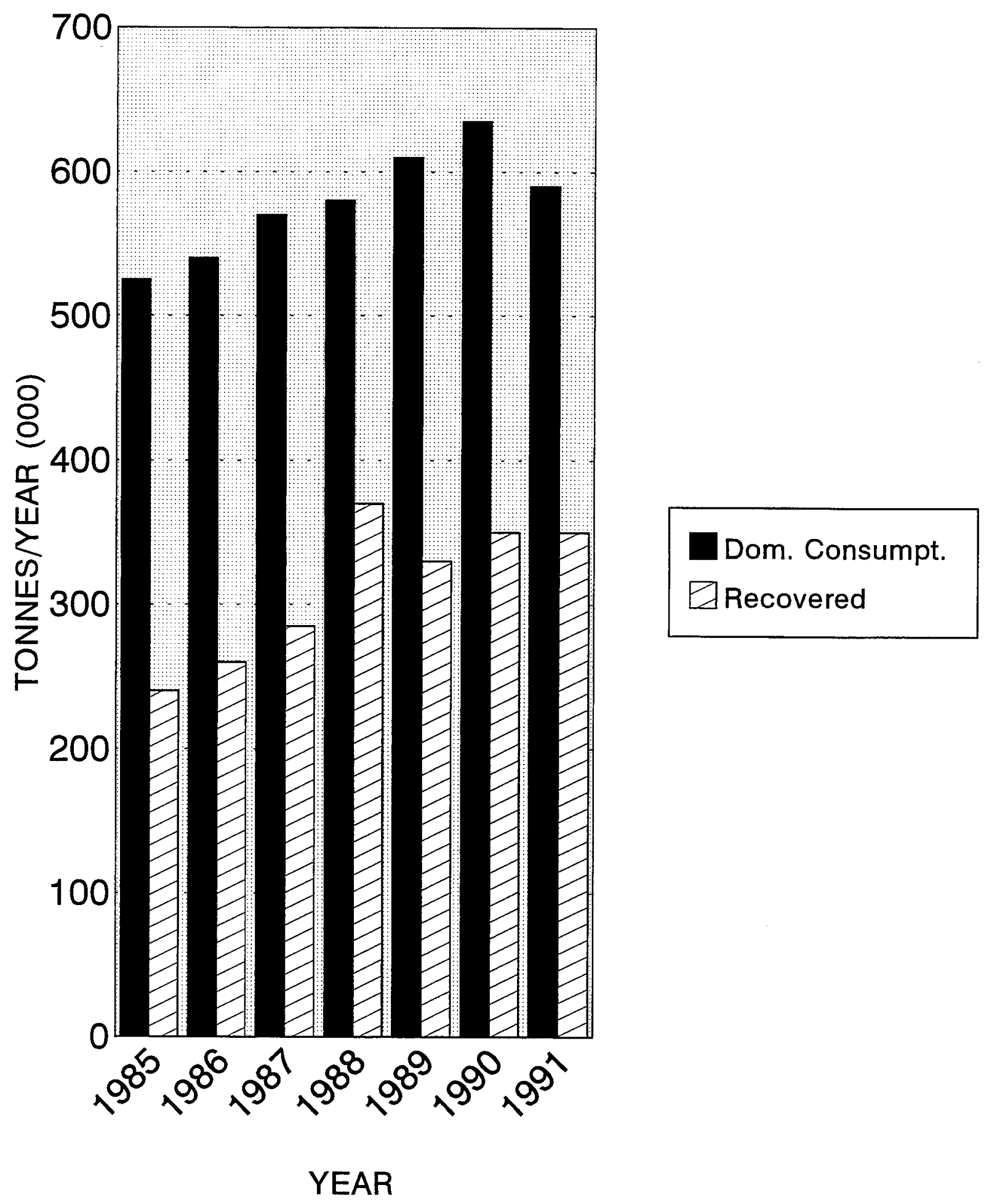




\section{FIGURE 3 \\ GLASS RECOVERY}

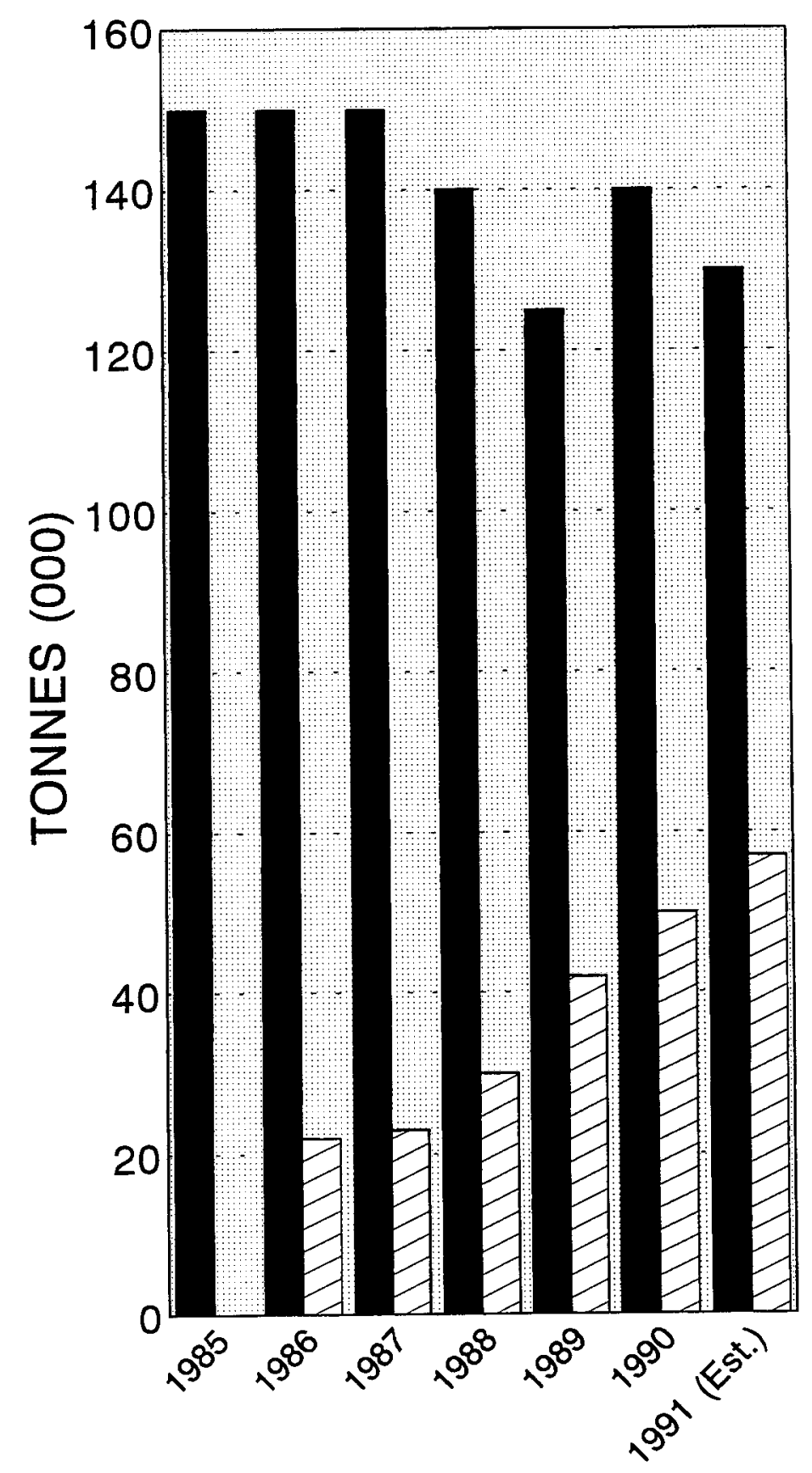

Domestic \& Imported

$\triangle$ Recycled

YEAR 


\section{FIGURE 4 \\ TREATMENT OF HOUSEHOLD WASTE}

(\% by Treatment Technique)

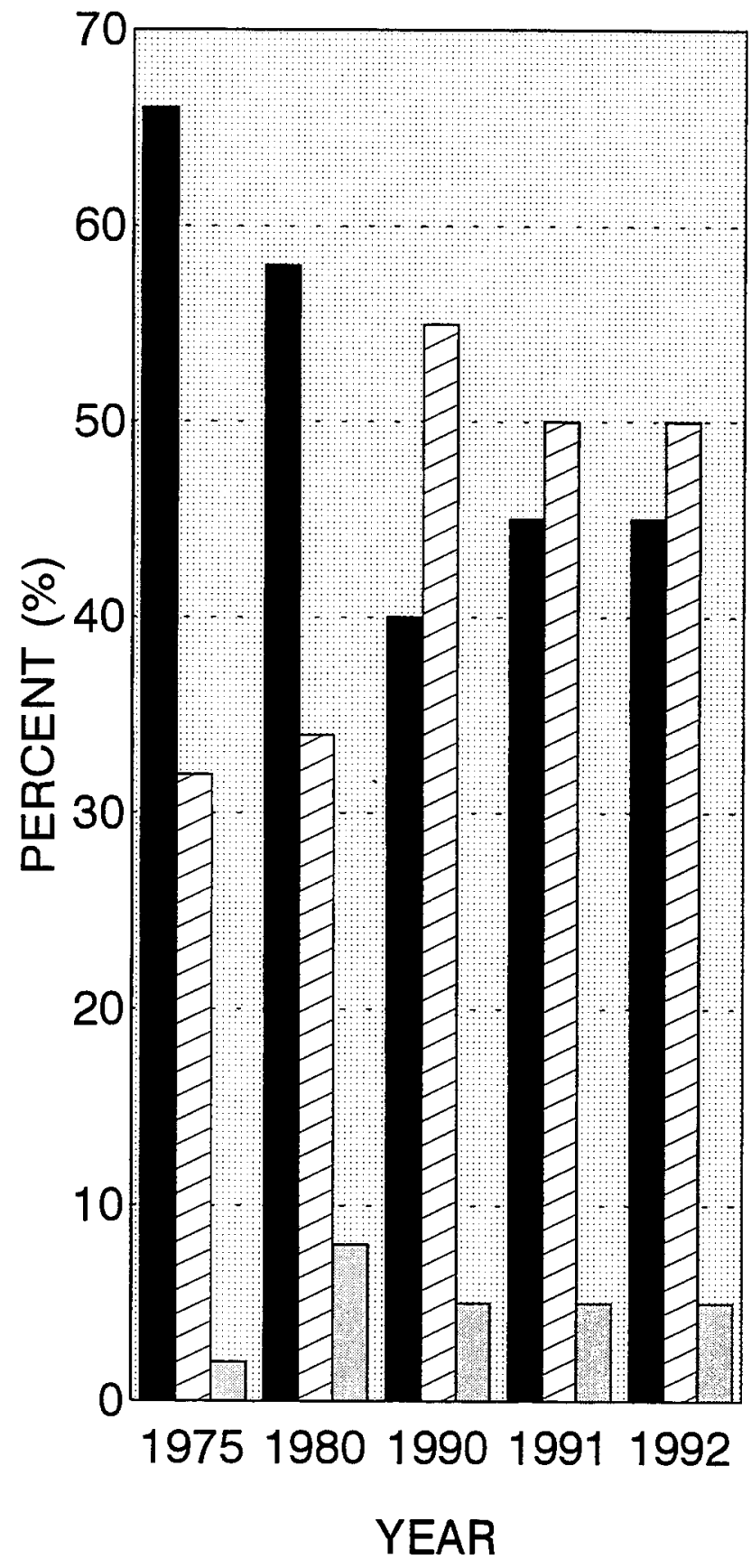

Landfill

$\square_{\text {Incineration }}$

$\square_{\text {Separation/Composting }}$

Source: RVF 
280 landfills in Sweden in 1992 (40 with methane gas recovery), down from more than 400 in 1980. Ninety percent of the landfills are owned and controlled by municipal interests.

Most of the energy generated from waste-to-energy facilities is used in district heating systems. In 1991, approximately $15 \%$ of the total district heating production in Sweden was from waste-to-energy plants. In some jurisdictions, waste-to-energy accounts for as much as $40 \%$ of the district heating requirements.

There are 11 separation or composting facilities which process approximately $5 \%$ of the domestic waste stream, producing 70,000 tons of fuel and 40,000 tons of compost. From 1965 to 1981, Swedish municipalities invested over SEK 1.4 billion in separation and composting facilities. These facilities mechanically separate the waste into different fractions (fuel, compost, and scrap). About $90 \%$ of the fuel component is combusted in existing waste-to-energy facilities, along with unsorted domestic waste. Most of the compost produced is used in covering landfills. 


\section{References}

AvfallsforskningsradetAFR, Environmentally Sound Recycling, Abstracts of Research Projects, December 1992, English.

AvfallsforskningsradetAFR, Environmentally Sound Recycling, Abstracts of Research Projects, September 1993, English.

AvfallsforskningsradetAFR, Environmentally Sound Products, Abstracts of Research Projects, September 1993, English.

AvfallsforskningsradetAFR, For a Low-Waste Ecocyclic Society, 1993, English.

AvfallsforskningsradetAFR, Safe Waste Deposition, Abstracts of Research Projects, September 1993, English.

AvfallsforskningsradetAFR, Systems Analysis, Abstracts of Research Projects, May 1993, English.

AvfallsforskningsradetAFR, The Development of Environmentally Sunder Products, 1992, English.

AvfalIsforskningsradetAFR, Waste Research Needs in Packaging, 1991, English.

AvfallsforskningsradetAFR, Workshop on Waste Charaterisation/Classification, 1993, English.

Barducci, Gianluca, "The RDF Gasifier of Florentine Area," 1992, English.

Bergstrom, Jan, "International Report: Flue Gas Cleaning in Sweden, Present Situation", Waste Management \& Research, 1993, English.

Blackadder, William H., Lundberg, Henrik, Rensfelt, Eric, and Waldheim, Lars, "Heat and Power Production via Gasification in the Range 5-50 $\mathrm{MW}_{\mathrm{e}}$," 1992 , English.

ENA Kraft, Biobransleeldat Kraftvarmeverk, Swedish.

Environmental Advisory Council, ECO Cycles, A Report from the Environmental Advisory Council, 1992, English.

Fangmark,Ingrid, Formation of Chlorinated Aromatic Compounds During Incineration- Application of Statistical Experimental Design, 1993, English.

Fangmark, Ingrid et al., "Influence of Combustion Parameters on the Formation of Polychlorinated Dibenzo-p-dioxin, Dibenzofurans, Benzenes, and Biphenyls and Polyaromatic Hydrocarbons in a Pilot Incinerator," Environmental Science Technology, 1993, English.

International, Environmental Report, "SWEDEN," Bureau of National Affairs, May 1990.

Johansson, Nils, Embassy of Sweden, Office of Science and Technology, Personal Correspondence, Environmental Topics, 1994. 
Marklund, Stellan, Dioxin Emissions and Environmental Immissions - A Study of Polychlorinated Dibenzodioxins and Dibenzofurans in Combustion Processes, 1990, English.

Modig, Staffan, "Waste Management in Sweden, a Problem Area with Many Solutions," Current Sweden, January 1991, English.

Naturvardsverket, Environment Protection in Sweden, the Major Environmental Issues, Means of Control, Administration, Research Grants Legislation. November 1984, English.

Naturvardsverk, Forslag tll kungorelser med foresklrifter om utsiapp fran anlagger for forbranning av kommunalt avfall, October 1993, Swedish.

Naturvardsverk, Information med anledning av Nox-deklarationen, August 1993, Swedish.

Naturvardsverket, Organizational Chart of Naturvardsverket, 1993, English.

Nordic Council of Minister's Nordic Environmental Report Group, The Nordic Environment - Present State, Trends, and Threats, 1993, English.

Nordisk Expertgrupp, NORDISK Dioxinrisk Bedomning, 1988, Swedish.

NUTEK, District Heating, Report of the International Committee on the Evaluation of Swedish Research in the Field of District Heating, 1993, English.

NUTEK, Energy in Sweden 1992, October 1992, English.

NUTEK, IP91/Kraftvarme Besultade Ansorkningar, 1993, Swedish.

NUTEK, Miljoanpassad lokal energiplanering, 1991, Swedish.

NUTEK, Research and Development, Forward Look and Proposals for 1993-1996, 1993, English.

NUTEK, Swedish Development: A Challenge For the Future, NUTEK Visions for the 1990s, 1992 , English.

NUTEK, Swedish National Board for Industrial and Technical Development, 1992, English.

Pedersen, Jorgen, "A Parametric Study of the Homogeneous Reaction between Methane, Hydrogen Chloride and Oxygen," Chemosphere, Vol. 22, Nos 1-2, 1991, English.

Pedersen, Jorgen and Kallman, Bertil, "The Chlorinating Species in Turbulent Flame Combustion of Methane with Hydrogen Chloride Present," Chemosphere, Vol. 22, Nos.1-2, 1991.

Retzner, Lotta, Swedish Solid Waste Management Association, personal Correspondence, Various Waste Management Topics, 1994.

Rylander, Hakan, "Municipal Solid Waste Management Activities in Sweden, SWANA Annual Conference, 1994.

Statens Energiverk/Naturvardsverket, Energy from Waste - Summary of the Study by the National Energy Administration and the National Swedish Environment Protection Board, 1986, English. 
Statistics Sweden, The Swedish Environment, 2nd Edition, 1994.

Steen, Bengt and Ryding, Sven-Olaf,AvfallsforskningsradetAFR, The EPS Enviro-Accounting Method, May 1993, English.

Stiftelsen REFORSK, Vi Stimulerar forskningen kring avfall och atervinning, Swedish.

Stromberg, Ann-Mari and Karlsson, Hans, "No ${ }_{x}$ Formation and Control Technologies," Stiftelsen for Varmeteknisk Forskning, 1992, English.

Studsvik Energy, Circulating Fluidised Bed Combustion, English.

Swedish Council for Building Research, Swedish National Energy Administration, et al., Tomorrow's Energy, Energy Research in Sweden 1990-1993, 1990, English.

Swedish Environmental Protection Board, Dioxins - A Program for Research and Action, 1988.

Svenska Renhallningsverks - Foreningens, Biologisk behandling av avfall, November 1993, Swedish.

Svensk Energi Utveckling, Gasification of Industrial Waste, September 1992, English.

The Information Group, The Product Ecology Project, Environmentally-sound product development based on the EPS system (Environmental Priority Strategies in product design), June 1993, English.

The Swedish Association of Solid Waste Management, Solid Waste Management In Sweden, August 1990, English.

The Swedish Institute, "Environmental Protection," Fact Sheet on Sweden, 1990.

The Swedish Institute, "General Facts on Sweden," Fact Sheet on Sweden, 1990.

The Swedish Institute, "Law and Justice in Sweden," Fact Sheet on Sweden, 1993.

The Swedish Ministry of the Environment and Energy, Official Government Paper 1986/87:157 on Waste Management, etc., May 1987, English.

The Swedish Solid Waste Management Association, "Solid Waste Management in Sweden," August 1990.

TPS Termiska Processer AB, TPS, English.

Tysklind, Mat, Multivariate Chemical Characterization and Modelling of Polychlorinated Dioxin and Dibenzofurans, 1993, English.

Umea Energi AB, Arsredovisning 1992, 1992, Swedish.

U.S. Department of Commerce, "Sweden Hazardous Waste Material Handling - Industry Analysis, International Trade Association, 1992. 


\section{Appendix A}

\section{Meetings and Tours Conducted in Sweden}




\section{Appendix A}

\section{Meetings and Tours Conducted in Sweden}

Monday, November 1, 1993

3:00 - 5:30 p.m.

Mr. Claes Åkesson

Head of Section

Ministry of the Environment and Natural Resources

S-103 33 Stockholm

Sweden

TEL 4687632032

FAX 468219170

Tuesday, November 2, 1993

9:00 a.m. - Noon

Dr. Lars Guldbrand

Principal Program Manager

Mr. Bengt Boström

Docent

Mr. Sten Åfeldt

Civ Ing

Nutek

Liljeholmsvägen 32

S-117 86 Stockholm, Sweden

TEL 4686819366

FAX 4686819328

1:00 - 2:00 p.m.

Dr. Sverker Högberg

Director

Avfallsforskningsrådet AFR

Swedish Waste Research Council

Box 47148

S-100 74 Stockholm, Sweden

TEL 4686819425

FAX 4686819219

5:30 - 7:30 p.m.

Mr. Bengt Jobin

Dep. Director

Federation of Swedish Industries

Environmental and Energy Department

Box 5501

S-114 85 Stockholm, Sweden

TEL 4687838102

FAX 4686623595 
Wednesday, November 3, 1993

9:00 a.m. - 2:00 p.m.

Mr. Bo Drougge

Principal Technical officer

Waste Management and Recycling Section

National Environmental Protection Agency

Englundavägen 13

S-171 85 SOLNA

Sweden

TEL 4687991000

FAX 4687991253

Thursday, November 4, 1993

9:00 a.m. - 2:00 p.m.

Mr. Erik Rensfelt

Managing Director

Mr. Niklas Berge

Managing

TPS Termiska Processer AB

Studsvik, S-611 82 Nyköping, Sweden

TEL 46155221300

FAX 46155263052

4:30 - 7:00 p.m.

Mr. Jan Bergström

President and CEO

Miljökonsulterna

Box 154, S-611 24 Nyköping, SWEDEN

TEL 46155222501

FAX 46155210384

Friday, November 5, 1993

9:00 a.m. - 2:00 p.m.

Mr. Bo Audelius

Fil. kand.

Ms. Lotta Retzner

Civilingenjör

R.V.F.

Swedish Association of Solid Waste Management

Österg. 30

21122 Malmö

TEL 40-10 4045

FAX 40-97 1094 
Tuesday, November 9, 1993

9:00 a.m. - 4:00 p.m.

Dr. Christofer Rappe

Fil. Dir.

Dr. Stellan Marklund

Research Scientist

Institute of Environmental Chemistry

University of Umea

S-901 87 Umeå, Sweden

TEL 090-16 5266

FAX 090-18 6155 


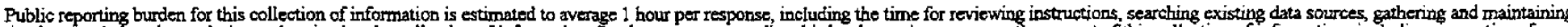

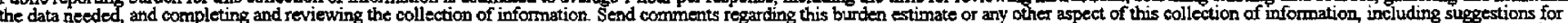

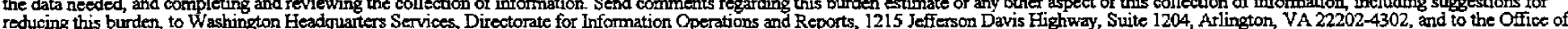
Management and Budget, Paperwork Reduction Project (0704-0188), Washington DC 20503.

\begin{tabular}{l|l|l}
$\begin{array}{l}\text { 1. AGENCY USE ONLY (Leave } \\
\text { blank) }\end{array}$ & $\begin{array}{c}\text { 2. REPORT DATE } \\
\text { May } 1995\end{array}$ & $\begin{array}{l}\text { 3. REPORT TYPE AND DA } \\
\text { Final subcontract report }\end{array}$ \\
\hline
\end{tabular}

4. TITLE AND SUBTITLE

Environmental Legislation and the Regulation of Waste Management in Sweden

Final Report

\section{AUTHOR(S)}

CSI Resource Systems, Incorporated

\section{PERFORMING ORGANIZATION NAME(S) AND ADDRESS(ES) \\ CSI Resource Systems, Incorporated}

8. PERFORMING

ORGANIZATION

REPORT NUMBER

DE95009219

10.

SPONSORING/MONITORING

AGENCY REPORT

NUMBER

NREL/TP-430-7976

National Renewable Energy Laboratory

1617 Cole Boulevard

Golden, CO 80401-3393

11. SUPPLEMENTARY NOTES

12a. DISTRIBUTION/AVAILABחITY STATEMENT

National Technical Information Service

U.S. Department of Commerce

5285 Port Royal Road

Springfield, VA 22161 12b. DISTRIBUTION CODE

UC-1414

\section{ABSTRACT (Maximum 200 words)}

This study examines the regulatory aspects of waste management in Sweden, with particular emphasis on regulating organic compounds produced by waste-to-energy facilities. Covered in the report are Sweden's regulatory environment, its history of setting emission limits on waste management facilities, and the current status of regulations.

\section{SUBJECT TERMS}

15. NUMBER OF PAGES

Sweden, waste-to-energy facilities, waste management facilities, government regulations, source reduction, reuse, recycling, separation and composting, landfilling, European Union.

50

16. PRICE CODE A03

\section{LIMITATION OF} ABSTRACT

\section{SECURITY \\ CLASSIFICATION \\ OF REPORT \\ Unclassified}

\section{SECURITY CLASSIFICATION}

OF THIS PAGE
OF ABSTRACT

\begin{tabular}{|l|l|l|l|}
\hline Unclassified & & & \\
\hline & & & \\
\hline & & & \\
\hline
\end{tabular}

